\title{
Spatial Distribution and Ecological Risk Assessment of Heavy Metals in Sediments from Pearl River Networks, South China
}

\author{
Jiangang Zhao ${ }^{* \#}$, Wenping Xie ${ }^{2 \#, ~ Q i y u a n ~ Z h a n g 1 ~}{ }^{1}$ Senhua He1, Yingjun Qin¹, Shangru Lu³, \\ Shuheng Zhang ${ }^{4}$, Changpeng $\mathrm{Ye}^{{ }^{*}}$
}

${ }^{1}$ Research Center of Hydrobiology, Jinan University, Guangzhou, China

${ }^{2}$ Key Laboratory of Tropical and Subtropical Fishery Resource Application and Cultivation of Ministry of Agriculture, Laboratory of Seafood Quality and Security Evaluation of Ministry of Agriculture, Pearl River Fisheries Research Institute, Chinese Academy of Fishery Sciences, Guangzhou, China

${ }^{3}$ College of Law and Politics, Guangdong Ocean University, Zhanjiang, China

${ }^{4}$ Guangdong Agricultural Products Quality and Safety Center, Guangzhou, China

Email: *zhjg@jnu.edu.cn, ${ }^{\star}$ tcpyes@jnu.edu.cn

How to cite this paper: Zhao, J.G., Xie, W.P., Zhang, Q.Y., He, S.H., Qin, Y.J., Lu, S.R., Zhang, S.H. and Ye, C.P. (2019) Spatial Distribution and Ecological Risk Assessment of Heavy Metals in Sediments from Pearl River Networks, South China. Open Access Library Journal, 6: e5709. https://doi.org/10.4236/oalib.1105709

Received: August 15, 2019

Accepted: September 15, 2019

Published: September 18, 2019

Copyright $\odot 2019$ by author(s) and Open Access Library Inc.

This work is licensed under the Creative Commons Attribution International License (CC BY 4.0).

http://creativecommons.org/licenses/by/4.0/

\begin{abstract}
Sediment samples collected from 21 sites of the Pearl River networks were investigated by the sequential extraction method. Multiple environmental indices were adopted to evaluate the present and potential risks. Results indicated that concentrations of $\mathrm{Cu}, \mathrm{Zn}, \mathrm{As}, \mathrm{Cd}$, and $\mathrm{Pb}$ in most of the sediments were substantially higher than their background values, and the primary sources of the contamination coming from municipal, industrial wastewater discharges and upstream mining were inferred by matrix analysis with comparing special distribution characteristics. Cd was the main factor causing the potential ecological risk in Pearl River networks. The potential mobility of heavy metals was shown in the decreasing order: $\mathrm{Cd}>\mathrm{Mn}>\mathrm{Co}>\mathrm{Zn}>\mathrm{Ni}>$ $\mathrm{Cu}>\mathrm{Pb}>\mathrm{As}>\mathrm{Cr}$.
\end{abstract}

\section{Subject Areas \\ Environmental Sciences, Hydrology}

\section{Keywords}

Heavy Metals, Pearl River Networks, Sequential Extraction, Sediments

\section{Introduction}

Heavy metals have been confirmed to dissolve in aquatic systems easily, and ${ }^{\#}$ First authors; ${ }^{*}$ Corresponding authors. 
caused realistic and potential serious hazards to organisms and human health. They are typically considered as a high ecological risk chemical pollutant and have attracted increasing attention [1] [2]. The contamination of heavy metals entering aquatic systems could be deposited and co-deposited into sediments by forming a variety of chemical fractions. The chemical stability of sediment-associated heavy metals may be subjected to the aquatic environment, such as the $\mathrm{pH}$ value, redox potential, ion strength, and presence of organic chelate. They could exhibit different physical and chemical behaviors, which is a concern in many studies. Once the aquatic environmental condition changed, the contamination of heavy metals may be transferred gradually into the water from sediments and becomes a potential source of biological-availability and toxicity [3] [4]. Heavy metals can be accumulated into aquatic animals from the water environment, and may reach higher levels than the water environment after the migration from sediment to water or to organisms [5] [6] [7]. Evaluating the risk of heavy metals in sediments could offer important information of the overall pollution level, but it was inadequate to perform an assessment on their potential mobility, bioavailability, and environmental risk [8] [9]. The detection and analysis of different chemical forms can facilitate in obtaining more information to determine the degree of mobility, bioavailability, and potential toxicity of heavy metals. The sequential extraction procedure is a widely-applied approach for the qualitative and quantitative analysis of different chemical forms and their binding states in sediments [10] [11].

The Pearl River networks are located in the Pearl River Delta region of South China, adjacent to the South China Sea, and is the channel connecting land and sea. It is not only one of the most densely populated and economically developed areas in China, but also in the South China primary fishery areas and passage for fish migratory from the South China Sea to the Pearl River. In recent years, along with rapid and extensive industrialization and agricultural growth, a large number of heavy metal contaminants from agriculture, domestic and municipal waters, mining, and processing have directly or indirectly discharged into the Pearl River networks, thus increasing the pollution of heavy metals in the surface sediments [12] [13] [14]. However, information on the distribution and environmental risk assessment of heavy metals in the Pearl River networks is scarce. In the present study, the sediments from 21 sites in the Pearl River networks were collected and analyzed for heavy metals. The primary objectives are: 1) to determine the concentration, chemical forms, and composition ratios of heavy metals in sediments to evaluate the level of contamination and distribution pattern, 2) to evaluate the pollution source, mobile status, bioavailability, and potential risk.

\section{Materials and Methods}

\subsection{Study Area and Sample Collection}

Samples were collected from the Pearl River networks with 21 sites from August 
to December of 2015. All sampling sites were distinguished into three areas: upstream (6 sites), midstream (7 sites), and estuary (8 sites) (Figure 1). The sediments were collected using a standard Van Veen grab sampler of effective area $250 \mathrm{~cm}^{2}$ and were homogenized using a Teflon spoon. The samples were transferred into labeled polyethylene containers under freezing conditions $\left(-4^{\circ} \mathrm{C}\right)$ for safe transportation to the laboratory. The samples were then air-dried for nearly 2 - 3 days under a fume hood, sieved, and subsequently ground with an agate mortar (grain sizes $<63 \mu \mathrm{m}$ ).

\subsection{Pretreatment and Analysis of Samples}

The determination of heavy metals in sediments were designed to separate metals into four operationally defined fractions modified based on the Tessier sequential extraction method [15] with a few modifications. The fractions were as follows: the exchangeable and carbonates $(\mathrm{EX}+\mathrm{C}), \mathrm{Fe}$ and $\mathrm{Mn}$ oxides (Fe/Mn-OX), organics, and residuals [14] [16] [17] [18].

\subsection{Analysis and Quality Control}

Chemical analysis was performed in the Pearl River Fisheries Research Institute, Chinese Academy of Fishery Sciences, China. Quality assurance and quality control (QA/QC) of the examined sediment samples were performed by the analysis of the procedural blank, duplicate samples, and the method of standard addition. All analytical instruments were calibrated daily, and the samples were determined according to the EPA method 3051A and 200.8 by ICP-MS (Agilent 7500-CX). The reference material from the Chinese national standard sediment sample GBW07436 was used to monitor the analysis. The results indicated no contamination during analysis, and the relative standard deviation of all the replicate samples was less than $10 \%$. The ratios of cumulative concentrations of the fractions to the independent total metal concentration ranged from $80 \%$ to $120 \%$.



Figure 1. Sampling sites. 
The detection limits were calculated by the relevant software in the database of the ICP-MS (ChemStation Software by Agilent). The lowest instrument determination limits of $\mathrm{Cr}, \mathrm{Mn}, \mathrm{Co}, \mathrm{Ni}, \mathrm{Cu}, \mathrm{Zn}, \mathrm{As}, \mathrm{Mo}, \mathrm{Cd}$, and $\mathrm{Pb}$ were 32.60, 20.13, $2.67,13.43,83.6,192.5,4.04,39.07,5.44$ and $13.21 \mu \mathrm{g} \cdot \mathrm{L}^{-1}$ respectively.

\subsection{Ecological Risk Assessment}

\subsubsection{Potential Migration Ability}

The risk assessment code (RAC) was used to reflect the heavy metals potential mobility, which has been widely used in the risk analysis of many studies [19] [11]. The RAC values of heavy metals were calculated according to the content of exchangeable and carbonate fractions to the total concentration ratios [20]. The guidelines for interpreting the RAC values are as the following: RAC $<1 \%$, no risk; $1 \% \leq \mathrm{RAC}<10 \%$, low risk; $10 \% \leq \mathrm{RAC}<30 \%$, medium risk; $30 \% \leq$ $\mathrm{RAC}<50 \%$, high risk; $\mathrm{RAC} \geq 50 \%$, extremely high risk.

\subsubsection{Enrichment Factor $(E F c)$}

The enrichment factor $(E F C)$ was applied to estimate and distinguish the heavy metals sourcing from anthropogenic or natural factor contributions, and to infer the information of dissolution in river sediments. The enrichment factors for each of the elements were calculated with the following formula:

$$
E F c=(\mathrm{Ms} / \mathrm{AIs}) \text { sample } /(\mathrm{Mo} / \mathrm{AIo}) \text { standard }
$$

where $E F c$. enrichment factor; Ms: concentration of metal " $\mathrm{X}$ " in the sample; AIs: concentration of reference element (AI) in the sample; Mo: background values of metal " $\mathrm{X}$ " in surface sediments of Pearl River estuary, is the corresponding background values of China's continental crust $(\mathrm{Cd}=0.055, \mathrm{~Pb}=15$, $\mathrm{Mo}=2, \mathrm{Cr}=63, \mathrm{Mn}=780, \mathrm{Ni}=57, \mathrm{Cu}=38, \mathrm{Zn}=86, \mathrm{As}=1.9, \mathrm{Co}=32$, $\mathrm{mg} / \mathrm{kg}$ ). An AIo of $7.8 \%$ was elected as the reference element [21]. The criteria for evaluating sediment $E F C$ were as follows: $E F_{C}<1$ indicates non-contamination by metal (crustal origin of the metal) and no enrichment; $1<E F C<2$ indicates low contamination or minor enrichment; $2<E F C<10$ indicates moderate contamination or moderate enrichment; $E F C>10$ indicates significant contamination by metals (non-crustal sources) or severe enrichment.

\subsubsection{Potential Ecological Risk}

The quantitative classification of potential ecological risk was proposed by Hakanson [22]. The potential ecological risk index was adopted to assess the degree of heavy metal pollution in sediments, according to the toxicity of heavy metal elements, the general migration and transformation law in sediments, and the regional sensitivity to heavy metal pollution. The formula for the potential ecological risk of the monomial element is as follows:

$$
E_{r}^{i}=T_{r}^{i} \times C_{s}^{i} / C_{n}^{i}
$$

In the formula, $E_{r}^{i}$ is the monomial potential ecological risk index; $T_{r}^{i}$ is a toxicity response parameter of a single contaminated element; $C_{s}^{i}$ is the meas- 
ured concentration of contaminated elements in the sediments $\left(\mathrm{mg} \cdot \mathrm{kg}^{-1}\right) ; C_{n}^{i}$ is the background value of heavy metals in the sediments. The biotoxicity coefficient $\left(T_{r}^{i}\right)$ of $\mathrm{Cu}, \mathrm{Zn}, \mathrm{Ni}, \mathrm{Cr}, \mathrm{Pb}, \mathrm{Cd}$ were 5, 1, 5, 2, 5, 30, respectively. The formula for the comprehensive evaluation method of various pollution elements is shown in formula (3):

$$
\mathrm{RI}=\sum E_{r}^{i}
$$

where RI is calculated as the sum of all potential ecological risk indexes of multiple metals. The terminology used to describe the individual potential ecological risk index $\left(E_{r}^{i}\right)$, integrated potential ecological risk index (RI), and potential ecological risk was suggested by Hakanson [22], where $E_{r}^{i}<40$ indicates a low potential ecological risk; $40<E_{r}^{i}<80$ indicates a moderate ecological risk; $80<$ $E_{r}^{i}<160$ indicates a considerable ecological risk; $160<E_{r}^{i}<320$ indicates a high ecological risk; $E_{r}^{i}>320$ indicates an extremely high ecological risk. RI < 95 indicates a low potential ecological risk; $95<\mathrm{RI}<190$ indicates a moderate ecological risk; $190<\mathrm{RI}<380$ indicates a considerable ecological risk, and RI > 380 indicates an extremely high ecological risk.

\subsection{Data Statistics}

Statistical analyses were conducted using Origin 8.0 (Origin Lab Corp., Northampton, MA, USA) and Excel 2013 (Microsoft Corp., Redmond, WA, USA).

\section{Results and Discussion}

\subsection{Concentrations of Heavy Metals in the Sediments}

The concentration of heavy metals was shown in the decreasing order: $\mathrm{Mn}>$ $\mathrm{Zn}>\mathrm{Cu}>\mathrm{Pb}>\mathrm{Cr}>\mathrm{Ni}>\mathrm{As}>\mathrm{Co}>\mathrm{Cd}$ (Figure 2). The average values were displayed and compared with the heavy metal target values of the Chinese Government for Marine sediments, the background of sediments of the Pear River estuary, and the average shale value. The sampling sites with concentrations of $\mathrm{Cr}$ and $\mathrm{Pb}$ exceeded the I Class Standard for Marine Sediment Quality, accounting for $42.8 \%$ and $71.4 \%$ of the total sampling sites respectively (Table 1). There were $66.7 \%$ of sampling sites with the concentrations of $\mathrm{Cu}, \mathrm{Zn}$ above the II
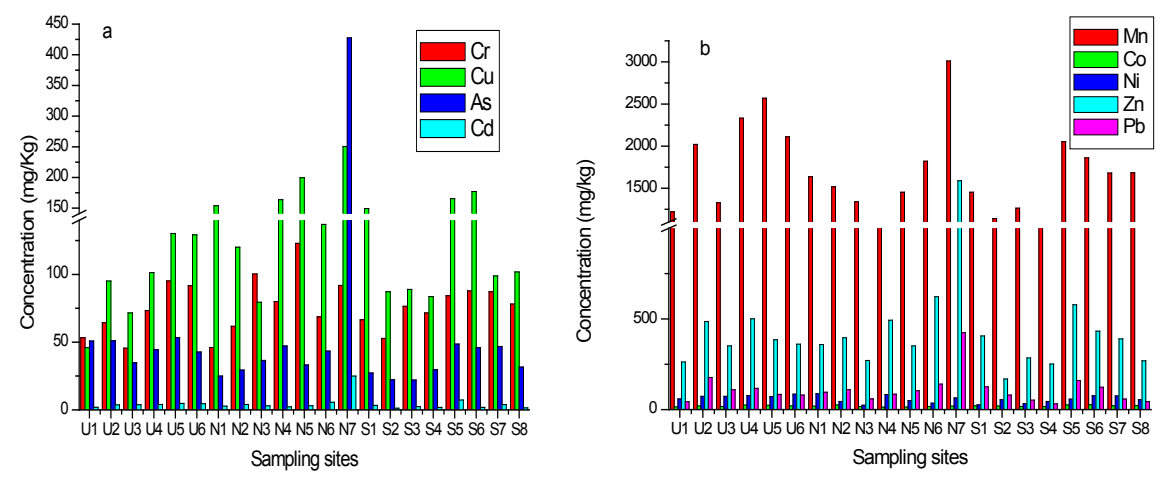

Figure 2. Distribution of heavy metals in the sediments. 
Table 1. Comparison of heavy metals concentration ( $\left.\mathrm{mg} \cdot \mathrm{kg}^{-1} \mathrm{dry} \mathrm{wt}\right)$ in the sediments from Pearl River networks.

\begin{tabular}{|c|c|c|c|c|c|c|c|c|c|}
\hline & $\mathrm{Cr}$ & $\mathrm{Mn}$ & Co & $\mathrm{Cu}$ & $\mathrm{Ni}$ & $\mathrm{Zn}$ & As & $\mathrm{Cd}$ & $\mathrm{Pb}$ \\
\hline Region means (this study) & 76.17 & 1698.28 & 19.94 & & 59.49 & 438.41 & 56.80 & 4.39 & 109.78 \\
\hline $\begin{array}{l}\text { Background of sediments of } \\
\text { the Pear River Estuary }\end{array}$ & 81.1 & na & na & & na & 100.7 & 22.9 & 0.2 & 44.0 \\
\hline $\begin{array}{c}\text { Standard for Marine } \\
\text { Sediment Quality I class }{ }^{a}\end{array}$ & 80 & na & na & 35 & na & 150 & na & 0.50 & 60 \\
\hline $\begin{array}{c}\text { Standard for Marine } \\
\text { Sediment Quality II class }{ }^{a}\end{array}$ & 150 & na & na & 100 & na & 350 & na & 1.50 & 130 \\
\hline $\begin{array}{c}\text { Standard for Marine } \\
\text { Sediment Quality III class }{ }^{a}\end{array}$ & 280 & na & na & 200 & na & 600 & na & 5.00 & 250 \\
\hline Average shale ${ }^{C}$ & 90 & na & 19 & na & 68 & 95 & 13 & 0.3 & 20 \\
\hline
\end{tabular}

na Not available; ${ }^{a} \mathrm{GAN}$ H., et al., 2010; ${ }^{b}$ National Standard of PR China (2002) (GB 18668-2002); ${ }^{\circ}$ Turedian and Wedepohl (1961).

class, and $91.7 \%$ of sampling sites with the concentrations of Cd varying II class and III class. Compared with the background of sediments of the Pear River Estuary, the average concentrations of $\mathrm{Zn}, \mathrm{As}, \mathrm{Cd}$, and $\mathrm{Pb}$ were as high as 4.35, $2.48,21.95$, and 2.49 times, which were higher with respect to their corresponding bench mark values. Cd was the most serious pollution element in this area, and the sampling sites with high concentration occurred in the northern (U5, U6) and middle (N3, N5, and N7) reaches. For other metals, i.e., Cr, Cu, Zn, Cd, and $\mathrm{Pb}$, the distribution characteristics of the middle reaches demonstrated a higher average concentration than in the northern or estuary sites. In particular, $\mathrm{Mn}, \mathrm{Zn}, \mathrm{Cu}, \mathrm{As}$, and $\mathrm{Zn}$ demonstrated the highest content at site N7.

The regional distribution characteristics of heavy metals in the sediments are closely related to the upstream input, local population, and industrial distribution. In the upstream Beijiang River Basin, a large number of mining and steel enterprises exist. Historically, illegal emissions from metal processing enterprises have resulted in large-scale Cd pollution. When the upstream pollutants enter the river networks, the flow becomes gentle and easy to precipitate, this may be a major reason for the higher distribution of heavy metals in the northern reaches (U2, U5, and U6). The hydrodynamic conditions became weakened and favored sediment deposition and followed by heavy metal accumulation. Pollution discharges from local metal processing, waste recycling, and the electronics industries are other major factors affecting the distribution of heavy metal pollution in sediments. For example, midstream sites (N3, N5, N7) surrounded by developed manufacturing industries and dense populations exhibited the highest pollution levels.

\subsection{Proportion of Various Fractions in the Sediments}

The evaluation of chemical fraction and composition of each metal in the sediments can provide useful information regarding the source, mobilization, avail- 
ability, and transport. The percentage of heavy metals associated with different fractions occurred in the following order (Figure 3):

$\mathrm{Cr}$ : residual $>\mathrm{Fe} / \mathrm{Mn}$ oxide $>$ organic matter/sulfide $>$ exchangeable with carbonate fraction.

$\mathrm{Ni}$ : residual $>\mathrm{Fe} / \mathrm{Mn}$ oxide $>$ exchangeable with carbonate fraction $>$ organic matter/sulfide.

As: residual $>\mathrm{Fe} / \mathrm{Mn}$ oxide $>$ organic matter/sulfide $>$ exchangeable with carbonate fraction.

$\mathrm{Cu}$ : residual $>$ organic matter/sulfide $>\mathrm{Fe} / \mathrm{Mn}$ oxide $>$ exchangeable with carbonate fraction.

$\mathrm{Zn}: \mathrm{Fe} / \mathrm{Mn}$ oxide $>$ residual $>$ exchangeable with carbonate fraction $>$ organic matter/sulfide.

$\mathrm{Pb}: \mathrm{Fe} / \mathrm{Mn}$ oxide $>$ residual $>$ organic matter/sulfide $>$ exchangeable with carbonate fraction.

Co: $\mathrm{Fe} / \mathrm{Mn}$ oxide $>$ residual $>$ exchangeable with carbonate fraction $>$ organic matter/sulfide.

$\mathrm{Cd}$ : exchangeable with carbonate fraction $>\mathrm{Fe} / \mathrm{Mn}$ oxide $>$ residual $>$ organic matter/sulfide.

$\mathrm{Mn}$ : exchangeable with carbonate fraction $>\mathrm{Fe} / \mathrm{Mn}$ oxide $>$ residual $>$ organic matter/sulfide.

The results of the distribution patterns of the eight metals indicated that for $\mathrm{Cr}, \mathrm{Ni}, \mathrm{As}$, and $\mathrm{Cu}$, the residual fraction was dominant in most of the samples, constituting $45.85 \%-85.27 \%, 45.38 \%-86.52 \%, 19.83 \%-72.37 \%$, and $66.38 \%$ $75.64 \%$ of their total concentrations, respectively. Some studies demonstrated

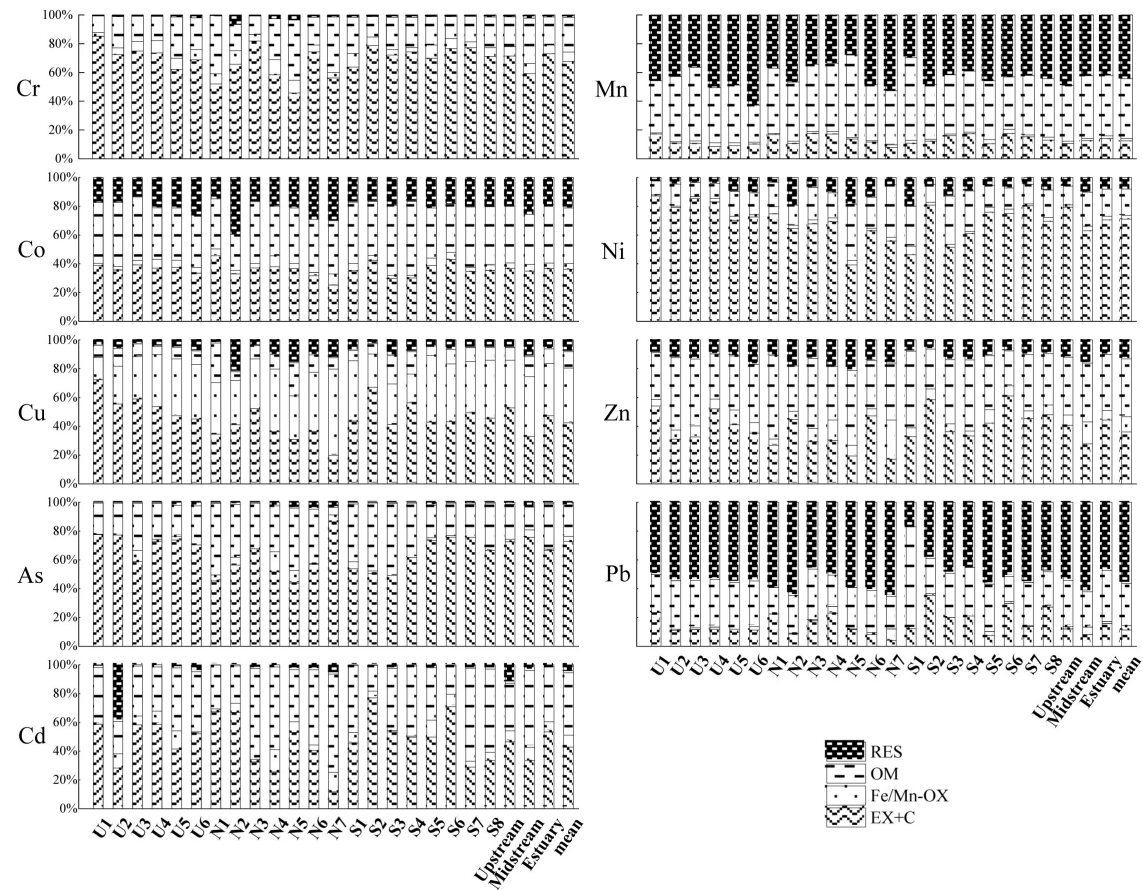

Figure 3. Proportion of different fractions in the sediments. 
that the residual fractions with higher proportions would be generally regarded as relatively stable, difficult to be absorbed, and utilized by organisms [23] [24] [25]. For $\mathrm{Zn}, \mathrm{Co}$, and $\mathrm{Pb}$, the $\mathrm{Fe} / \mathrm{Mn}$ oxide fraction exhibited the largest proportion, constituting $17.00 \%-61.08 \%, 35.94 \%-51.27 \%$, and $11.80 \%-70.96 \%$, respectively. They could form stable complexes with Fe or Mn oxides [1]. In the $\mathrm{Fe} / \mathrm{Mn}$ oxide fraction, heavy metals were adsorbed or co-precipitated in the sediments, and could be mobilized or transferred into aquatic organisms in hypoxic environments [26]; therefore, the fraction of Fe/Mn oxides could be considered as a potential source of heavy metals in the river sediment. The highest proportion with exchangeable and carbonate fractions existed in $\mathrm{Cd}$ and $\mathrm{Mn}$, with Cd (16.93\% - 65.48\%) and Mn (27.74\% - 62.69\%), respectively. In the exchangeable fraction and carbonate fraction, heavy metals were weakly attached to the sediments by precipitation or co-precipitation. When the ionic composition or $\mathrm{pH}$ changed, they could be released easily into water, which was consistent with other studies [17] [27].

In the sediments of the Pearl River networks, the proportion of $\mathrm{Cd}$ associated with exchangeable and carbonate fractions was the highest. The primary reason was attributable to the aquatic environment containing a high concentration of $\mathrm{HCO}_{3}^{-}$, which originated from the Karst area of the Pearl River upstream basin, and a large amount of calcium lime was used as a flocculant to adsorb and co-precipitate $\mathrm{Cd}^{-}$during the cadmium pollution accident that occurred in the Beijiang River, owing to formed $\mathrm{CdCO}_{3}^{-}$in the neutral $\mathrm{pH}$ condition. The exchangeable and carbonate fractions of the sediments are more labile and readily leachable or bio-available, because the adsorbed heavy metal ions can be released into water when the concentration of the hydrogen ion increases in the water, in comparison with other fractions. Therefore, the concentration and accounted proportion of the exchangeable and carbonate fractions in the sediments can be directly related to the bioavailability, mobility, and environmental impact of the heavy metals [28] [29]. Based on the percentage of exchangeable with carbonate fractions to the total concentrations, the mobility of the heavy metals investigated in the sediments of the Pearl River networks were observed in the following order: $\mathrm{Cd}>\mathrm{Mn}>\mathrm{Co}>\mathrm{Zn}>\mathrm{Ni}>\mathrm{Cu}>\mathrm{Pb}>\mathrm{As}>\mathrm{Cr}$. According to the results, for $\mathrm{Cd}$ and $\mathrm{Mn}$, the fractions with the combination of exchangeable and carbonate were found to be predominant in most samples, and could be released gradually from the sediment into the water and organisms.

\subsection{Risk Assessment of Heavy Metals in the Sediments}

\subsubsection{Risk Assessment Code (RAC)}

The results indicated that the RAC values for $\mathrm{Cr}$ and As mobilization ranged from 0.41 to 6.69 and from 0.33 to 4.68 respectively, corresponding to "no risk" or "low risk" in all sites. The RAC values of $\mathrm{Cu}, \mathrm{Pb}, \mathrm{Co}, \mathrm{Zn}$, and $\mathrm{Mn}$ ranged from 2.11 to $22.12,0.05$ to $39.29,13.54$ to $39.56,6.27$ to 21.09 , and 27.74 to 62.69 , respectively (Figure 4(a), Figure 4(b)). Furthermore, 28.5\% of sampling sites $(\mathrm{Cu}), 71.4 \%$ of sampling sites $(\mathrm{Zn})$, and $90 \%$ of sampling sites $(\mathrm{Mn})$ exhibited 

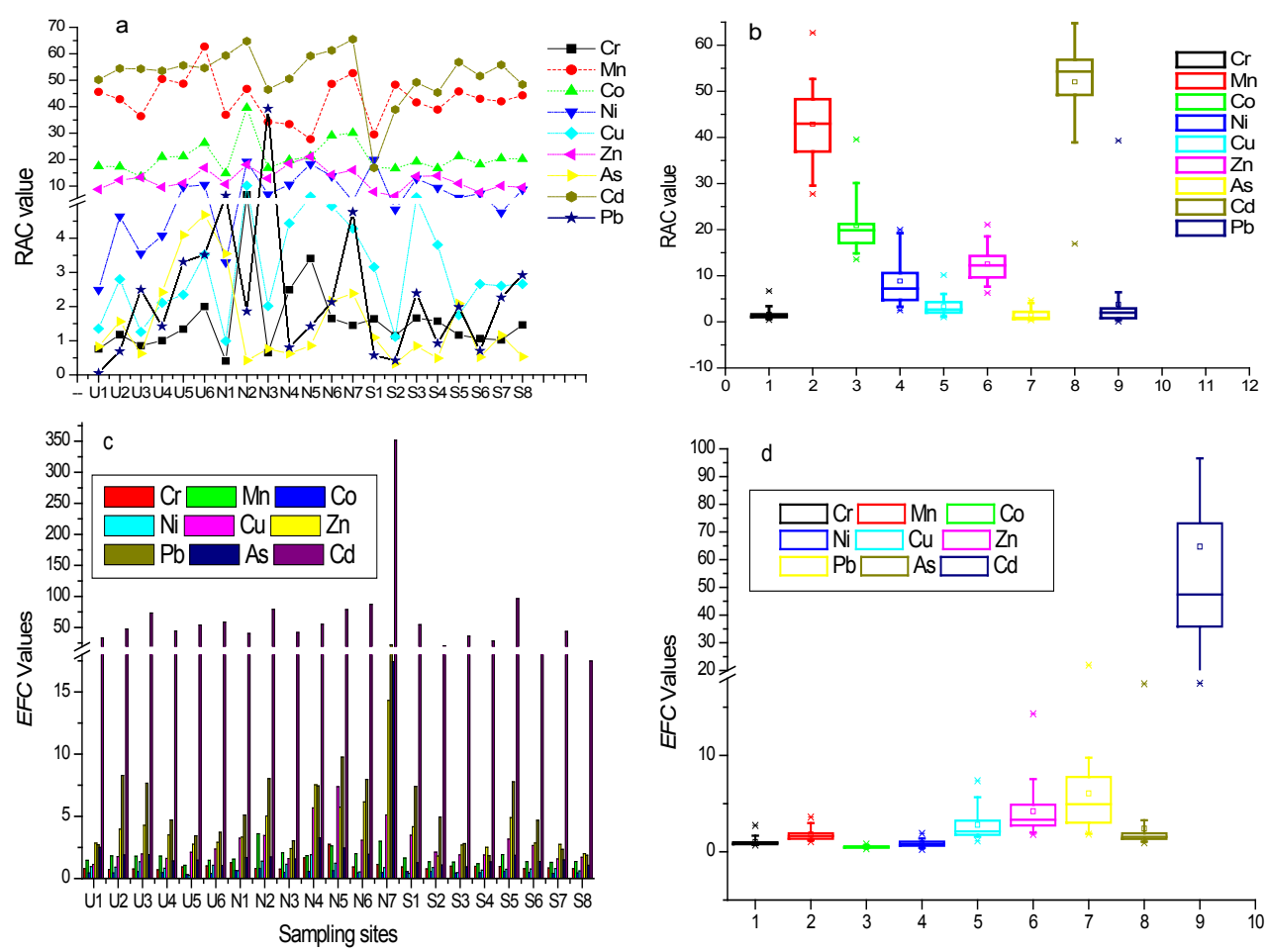

Figure 4. Ecological risk assessment (RAC values calculated for all sediment samples). (a) Distribution of sampling sites; (b) Comparison with heavy metals; (c) $E F c$ values of sediments from different sampling sites; (d) $E F c$ values by comparing with heavy metals.

"medium risk". For $\mathrm{Pb}$ mobilization, some samples showed "high risk", but the majority sites were "no risk" or "low risk". The RAC of Cd varied from 16.93 to 65.4 , and over $76.71 \%$ of the sampling sites were "extremely high risk". The results indicated that the toxic metals of $\mathrm{Zn}$ and $\mathrm{Cd}$ would be more abundant and bio-available than the other metals. The spiking sites were distributed in the midstream reaches, especially in sampling sites $\mathrm{N} 2$ to $\mathrm{N} 7$ along the river.

\subsubsection{Enrichment Factor $(E F c)$}

The contamination of heavy metals in sediments was considered to be derived from human activities and the natural weather; however, it was difficult to obtain the full information to distinguish the pollutant sources by a typical analysis and a comparison to the polluted level. Many studies have highlighted that heavy metals in the sediments coming from natural sources exhibit a higher correlation compared to the background value and reference elements than from anthropogenic sources; therefore, the metal to metal relative ratios were widely used because it could better assess and distinguish their polluted sources [21] [30]. The application of enrichment factors indicated that the ratio ranges of $\mathrm{Cr}, \mathrm{Co}$, and $\mathrm{Ni}$ were $0.70-2.74,0.32-0.81$, and 0.26 - 1.91, respectively (Figure 4(c), Figure 4 (d)), with mean values $0.93,0.47$, and 0.82 , respectively. Most of the samples were classified as "no contamination", which confirmed that the metals primarily came from natural sources. The ratio ranges of $\mathrm{Mn}$ and As were $1.06-3.60$ and $0.94-17.46$, with mean values 1.64 and 1.56 , respectively, corresponding to 
the "low contamination or minor enrichment" category for the EFC values, except for Mn in sites of N2 (3.60), N5 (2.62), and N7 (2.99), and As in sites of U1 (2.5), N4 (3.27), N5 (2.45), and N7 (17.43). The EFC values of $\mathrm{Cu}, \mathrm{Zn}$ and $\mathrm{Pb}$ ranged from 1.31 to 7.83 (mean, 2.12), 1.81 to 14.32 (mean, 3.33), and 1.83 to 21.90 (mean, 4.94). For $61.9 \%$ of $\mathrm{Cu}, 90.4 \%$ of $\mathrm{Zn}$, and $95.2 \%$ of $\mathrm{Pb}$, the category of $E F C$ values was "moderately contaminated or moderate enrichment." The primary polluted sites are distribution midstream reaches, especially (N2, N4, N5, N6 and N7); thus, it can be concluded that different degrees of anthropogenic contamination occurred. For Cd, "significantly contaminated" was found in most of the sites; the ratios exceeded as high as 17.49 to 351.45 times with the natural background level, indicating the obvious enrichment and anthropogenic sources. The distribution of $\mathrm{Cd}$ in the midstream sites was significantly higher, such as N7 (351.45), N6 (87.26), and N5 (78.74), than that of most sites in the estuary and upstream; the results are consistent with those of $\mathrm{Cu}, \mathrm{Zn}$, and $\mathrm{Pb}$.

\subsubsection{Potential Ecological Risk Assessment}

The assessment indexes, including the single potential ecological risk index, comprehensive potential ecological risk index, and grading standard were calculated using the formula with the evaluation of the potential ecological risks of $\mathrm{Cr}$, $\mathrm{Ni}, \mathrm{Zn}, \mathrm{Cu}, \mathrm{Pb}$, and $\mathrm{Cd}$ in sediments. The results indicated that the descending order of the single-pollutant ecological risk grade ( $E_{r}^{i}$, average values) of the heavy metals was as follows: $\mathrm{Cd}(399.09)>\mathrm{Pb}(36.59)>\mathrm{Cu}(16.48)>\mathrm{Ni}$ $(15.66)>\operatorname{Zn}(5.10)>\operatorname{Cr}(2.42)$, and the average contribution rate of each metal to the comprehensive potential ecological risk index (RI) was $84 \%$ for $\mathrm{Cd}, 7.7 \%$ for $\mathrm{Pd}, 3.5 \%$ for $\mathrm{Cu}, 3.3 \%$ for $\mathrm{Ni}, 1.1 \%$ for $\mathrm{Zn}, 1.1 \%$ for $\mathrm{Zn}$, and $1.0 \%$ for $\mathrm{Cr}$, which revealed that $\mathrm{Cd}$ was the primary metal contributing to the sediment toxicity (Table 2).

Table 2. Evaluation of potential risk index of heavy metal in the sediments of Pearl River networks.

\begin{tabular}{|c|c|c|c|c|c|c|c|}
\hline \multirow{2}{*}{ Locations } & \multicolumn{6}{|c|}{$E_{r}^{i}$} & \multirow{2}{*}{ RI } \\
\hline & $\mathrm{Cr}$ & $\mathrm{Ni}$ & $\mathrm{Zn}$ & $\mathrm{Cu}$ & $\mathrm{Cd}$ & $\mathrm{Pb}$ & \\
\hline U1 & $1.69^{\mathrm{a}}$ & $15.36^{\mathrm{a}}$ & $3.05^{\mathrm{a}}$ & $6.05^{\mathrm{a}}$ & $177.27^{\mathrm{d}}$ & $14.51^{\mathrm{a}}$ & $217.94^{\mathrm{C}}$ \\
\hline $\mathrm{U} 2$ & $2.04^{\mathrm{a}}$ & $19.26^{\mathrm{a}}$ & $5.64^{\mathrm{a}}$ & $12.52^{\mathrm{a}}$ & $337.27^{\mathrm{e}}$ & $58.93^{\mathrm{b}}$ & $435.66^{\mathrm{D}}$ \\
\hline U3 & $1.45^{\mathrm{a}}$ & $19.24^{\mathrm{a}}$ & $4.08^{\mathrm{a}}$ & $9.42^{\mathrm{a}}$ & $349.09^{\mathrm{e}}$ & $36.51^{\mathrm{a}}$ & $419.78^{D}$ \\
\hline $\mathrm{U} 4$ & $2.33^{\mathrm{a}}$ & $20.47^{\mathrm{a}}$ & $5.82^{\mathrm{a}}$ & $13.34^{\mathrm{a}}$ & $366.36^{\mathrm{e}}$ & $39.13^{\mathrm{a}}$ & $447.46^{\mathrm{D}}$ \\
\hline U5 & $3.02^{\mathrm{a}}$ & $19.11^{\mathrm{a}}$ & $4.48^{\mathrm{a}}$ & $17.13^{\mathrm{a}}$ & $437.27^{\mathrm{e}}$ & $27.83^{\mathrm{a}}$ & $508.84^{\mathrm{D}}$ \\
\hline U6 & $2.91^{\mathrm{a}}$ & $22.29^{\mathrm{a}}$ & $4.20^{\mathrm{a}}$ & $17.00^{\mathrm{a}}$ & $420.91^{\mathrm{e}}$ & $26.71^{\mathrm{a}}$ & $494.02^{\mathrm{D}}$ \\
\hline N1 & $1.46^{\mathrm{a}}$ & $22.97^{\mathrm{a}}$ & $4.17^{\mathrm{a}}$ & $20.26^{\mathrm{a}}$ & $251.82^{\mathrm{d}}$ & $31.89^{\mathrm{a}}$ & $332.58^{C}$ \\
\hline N2 & $1.96^{\mathrm{a}}$ & $11.81^{\mathrm{a}}$ & $4.60^{\mathrm{a}}$ & $15.80^{\mathrm{a}}$ & 361.82 & $36.77^{\mathrm{a}}$ & 432.76 \\
\hline N3 & $3.18^{\mathrm{a}}$ & $6.26^{\mathrm{a}}$ & $3.15^{\mathrm{a}}$ & $10.46^{\mathrm{a}}$ & $273.64^{\mathrm{d}}$ & $19.80^{\mathrm{a}}$ & $316.49^{C}$ \\
\hline N4 & $2.54^{\mathrm{a}}$ & $21.81^{\mathrm{a}}$ & $5.73^{\mathrm{a}}$ & $21.55^{\mathrm{a}}$ & $209.09^{d}$ & $28.29^{\mathrm{a}}$ & $289.00^{\mathrm{C}}$ \\
\hline
\end{tabular}




\section{Continued}

\begin{tabular}{cccccccc}
\hline N5 & $3.90^{\mathrm{a}}$ & $13.01^{\mathrm{a}}$ & $4.08^{\mathrm{a}}$ & $26.27^{\mathrm{a}}$ & $280.00^{\mathrm{d}}$ & $34.72^{\mathrm{a}}$ & $361.99^{\mathrm{C}}$ \\
N6 & $2.18^{\mathrm{a}}$ & $9.24^{\mathrm{a}}$ & $7.24^{\mathrm{a}}$ & $18.01^{\mathrm{a}}$ & $512.73^{\mathrm{e}}$ & $46.81^{\mathrm{a}}$ & $596.21^{\mathrm{D}}$ \\
N7 & $2.92^{\mathrm{a}}$ & $16.81^{\mathrm{a}}$ & $18.49^{\mathrm{a}}$ & $32.97^{\mathrm{a}}$ & $2269.09^{\mathrm{e}}$ & 141.35 & $2481.61^{\mathrm{D}}$ \\
S1 & $2.11^{\mathrm{a}}$ & $6.98^{\mathrm{a}}$ & $4.72^{\mathrm{a}}$ & $19.64^{\mathrm{a}}$ & $308.18^{\mathrm{d}}$ & $41.96^{\mathrm{b}}$ & $383.60^{\mathrm{D}}$ \\
S2 & $1.68^{\mathrm{a}}$ & $14.28^{\mathrm{a}}$ & $1.96^{\mathrm{a}}$ & $11.48^{\mathrm{a}}$ & $110.91^{\mathrm{c}}$ & $26.80^{\mathrm{a}}$ & $167.10^{\mathrm{B}}$ \\
S3 & $2.43^{\mathrm{a}}$ & $8.62^{\mathrm{a}}$ & $3.31^{\mathrm{a}}$ & $11.70^{\mathrm{a}}$ & $220.91^{\mathrm{d}}$ & $17.27^{\mathrm{a}}$ & $264.24^{\mathrm{C}}$ \\
S4 & $2.27^{\mathrm{a}}$ & $11.74^{\mathrm{a}}$ & $2.92^{\mathrm{a}}$ & $11.01^{\mathrm{a}}$ & $164.55^{\mathrm{d}}$ & $10.63^{\mathrm{a}}$ & $203.12^{\mathrm{C}}$ \\
S5 & $2.67^{\mathrm{a}}$ & $15.18^{\mathrm{a}}$ & $6.72^{\mathrm{a}}$ & $21.77^{\mathrm{a}}$ & $663.64^{\mathrm{e}}$ & $53.38^{\mathrm{b}}$ & $763.37^{\mathrm{D}}$ \\
S6 & $2.79^{\mathrm{a}}$ & $20.08^{\mathrm{a}}$ & $5.03^{\mathrm{a}}$ & $23.29^{\mathrm{a}}$ & $165.45^{\mathrm{d}}$ & $41.14^{\mathrm{b}}$ & $257.77^{\mathrm{C}}$ \\
S7 & $2.77^{\mathrm{a}}$ & $19.88^{\mathrm{a}}$ & $4.53^{\mathrm{a}}$ & $13.01^{\mathrm{a}}$ & $360.91^{\mathrm{e}}$ & $19.39^{\mathrm{a}}$ & $420.50^{\mathrm{D}}$ \\
Average & $2.42^{\mathrm{a}}$ & $15.66^{\mathrm{a}}$ & $5.10^{\mathrm{a}}$ & $16.48^{\mathrm{a}}$ & $399.09^{\mathrm{e}}$ & $36.59^{\mathrm{a}}$ & $475.34^{\mathrm{D}}$ \\
Min & $1.45^{\mathrm{a}}$ & $6.26^{\mathrm{a}}$ & $1.96^{\mathrm{a}}$ & $6.05^{\mathrm{a}}$ & $110.91^{\mathrm{c}}$ & $10.63^{\mathrm{a}}$ & $167.10^{\mathrm{B}}$ \\
Max & $3.90^{\mathrm{a}}$ & $22.97^{\mathrm{a}}$ & $18.49^{\mathrm{a}}$ & $32.97^{\mathrm{a}}$ & $2269.09^{\mathrm{e}}$ & $141.35^{\mathrm{c}}$ & $2481.61^{\mathrm{D}}$ \\
SD & 0.61 & 5.15 & 3.33 & 6.38 & 448.87 & 27.27 & 482.02 \\
\hline
\end{tabular}

Note: "a" $E_{r}^{i}<40$, Low risk; "b" $40 \leq E_{r}^{i}<80$, Moderate risk; "c" $80 \leq E_{r}^{i}<160$, considerable ecological risk; "d" $160 \leq E_{r}^{i}<320$, High ecological risk; "e" $E_{r}^{i} \geq 320$, Very high ecological risk. "A" RI $<95$, Low potential ecological risk; "B" $95 \leq \mathrm{RI}<190$, Moderate potential ecological risk; "C" $190 \leq \mathrm{RI}<380$, Considerable potential ecological risk; " $\mathrm{D}$ ” $\mathrm{RI} \geq 380$, Very high potential ecological risk.

The RI value in the sediments ranged from 167.7 to 2481.6, with an average of $475.3,57 \%$ of the sampling sites exhibited "very high ecological risk". Particularly, N6 (596.2), N7 (2481.6), and S5 (763.4) exhibited the higher potential ecological risk and disperse distribution characteristics. Furthermore, they were all located in the major area of the Pearl River delta around developed processing industries, a highly dense population, and a large number of electronics.

\section{Conclusion}

The mobility of heavy metals in sediments of the Pearl River networks was indicated as the decreasing order: $\mathrm{Cd}>\mathrm{Mn}>\mathrm{Co}>\mathrm{Zn}>\mathrm{Ni}>\mathrm{Cu}>\mathrm{Pb}>\mathrm{As}>\mathrm{Cr}$. Cd and $\mathrm{Mn}$ showed the higher mobility and bioavailability than the other heavy metals. The enrichment factor demonstrated that most of the samples of $\mathrm{Cr}, \mathrm{Co}$, and $\mathrm{Ni}$ were classified under "no contamination", which confirmed that the metal primarily originated from natural sources. The evaluation results indicated that $\mathrm{Cu}, \mathrm{Zn}, \mathrm{Pb}$, and $\mathrm{Cd}$ with peaking sites at $\mathrm{N} 7$, owing to the high density of population and industrial distribution. Among the heavy metals, Cd was the primary metal contributing to the sediment toxicity; the average contribution rate to the comprehensive potential ecological risk index constituted $84 \%$ in the region, and required more attention.

\section{Acknowledgements}

This work was supported by the Special Fund for Agro-scientific Research in the 
Public Interest (No. 201503108), Science and Technology Planning Project of Guangzhou, China (No. 201604020029, 201804010494), Dedicated Fund for Promoting High-quality Marine Economic Development in Guangdong Province (GDOE-2019-A31), Guangdong Marine and Fishery Bureau Science and Technology Project (No. SDYY-2018-08; A201601B05) and China Innovation \& Entrepreneurship Competition for Undergraduate (82619300, 82619225).

\section{Conflicts of Interest}

The authors declare no conflicts of interest regarding the publication of this paper.

\section{References}

[1] Wang, Y., Yang, Z., Shen, Z., Tang, Z., Niu, J. and Gao, F. (2011) Assessment of Heavy Metals in Sediments from a Typical Catchment of the Yangtze River, China. Environmental Monitoring and Assessment, 172, 407-417. https://doi.org/10.1007/s10661-010-1343-5

[2] Hahladakis, J.N., Vasilaki, G., Smaragdaki, E. and Gidarakos, E. (2016) Application of Ecological Risk Indicators for the Assessment of Greek Surficial Sediments Contaminated by Toxic Metals. Environmental Monitoring and Assessment, 188, 271. https://doi.org/10.1007/s10661-016-5275-6

[3] Zhang, L., Yin, K., Wang, L., Chen, F., Zhang, D. and Yang, Y. (2009) The Sources and Accumulation Rate of Sedimentary Organic Matter in the Pearl River Estuary and Adjacent Coastal Area, Southern China. Estuarine, Coastal and Shelf Science, 85, 190-196.

[4] Guillén, M.T., Delgado, J., Albanese, S., Nieto, J.M., Lima, A. and De Vivo, B. (2012) Heavy Metals Fractionation and Multivariate Statistical Techniques to Evaluate the Environmental Risk in Soils of Huelva Township (SW Iberian Peninsula). Journal of Geochemical Exploration, 119-120, 32-43.

[5] Sapkota, A., Sapkota, A.R., Kucharski, M., Burke, J., Mckenzie, S., Walker, P., et al. (2008) Aquaculture Practices and Potential Human Health Risks: Current Knowledge and Future Priorities. Environment International, 34, 1215-1226. https://doi.org/10.1016/j.envint.2008.04.009

[6] Yi, Y., Yang, Z. and Zhang, S. (2011) Ecological Risk Assessment of Heavy Metals in Sediment and Human Health Risk Assessment of Heavy Metals in Fishes in the Middle and Lower Reaches of the Yangtze River Basin. Environmental Pollution, 159, 2575-2585.

[7] Gu, Y.G., Wang, Z.H., Lu, S.H., Jiang, S.J., Mu, D.H. and Shu, Y.H. (2012) Multivariate Statistical and GIS-Based Approach to Identify Source of Anthropogenic Impacts on Metallic Elements in Sediments from the Mid Guangdong Coasts, China. Environmental Pollution, 163, 248-255.

[8] Arain, M.B., Kazi, T.G., Jamali, M.K., Baig, J.A., Afridi, H.I., Jalbani, N., et al. (2009) Comparison of Different Extraction Approaches for Heavy Metal Partitioning in Sediment Samples. Pedosphere, 19, 476-485. https://doi.org/10.1016/S1002-0160(09)60140-5

[9] Smith, B.J., McAlister, J.J., Roe, H.M. and Royle, S.A. (2011) Metal and Oxalate Contamination in a Suburban Watershed in the Greater Toronto Area: The Benefits of Combining Acid Leach and Selective Extraction Procedures. Journal of Environmental Management, 92, 848-858. 
https://doi.org/10.1016/j.jenvman.2010.10.036

[10] Hejabi, A.T. and Basavarajappa, H.T. (2013) Heavy Metals Partitioning in Sediments of the Kabini River in South India. Environmental Monitoring and Assessment, 185, 1273-1283. https://doi.org/10.1007/s10661-012-2631-z

[11] Sungur, A., Soylak, M., Yilmaz, S. and Özcan, H. (2014.) Determination of Heavy Metals in Sediments of the Ergene River by BCR Sequential Extraction Method. Environmental Earth Sciences, 72, 3293-3305. https://doi.org/10.1007/s12665-014-3233-6

[12] Li, X., Shen, Z., Wai, O.W. and Li, Y.S. (2001) Chemical forms of Pb, $\mathrm{Zn}$ and $\mathrm{Cu}$ in the Sediment Profiles of the Pearl River Estuary. Marine Pollution Bulletin, 42, 215-223. https://doi.org/10.1016/S0025-326X(00)00145-4

[13] Zhou, H.Y., Peng, X.T. and Pan, J.M. (2004) Distribution, Source and Enrichment of Some Chemical Elements in Sediments of the Pearl River Estuary, China. Continental Shelf Research, 24, 1857-1875. https://doi.org/10.1016/j.csr.2004.06.012

[14] Liu, B., Hu, K., Jiang, Z., Yang, J., Luo, X. and Liu, A. (2011) Distribution and Enrichment of Heavy Metals in a Sediment Core from the Pearl River Estuary. Environmental Earth Sciences, 62, 265-275. https://doi.org/10.1007/s12665-010-0520-8

[15] Tessier, A., Campbell, P.G. and Bisson, M. (1979) Sequential Extraction Procedure for the Speciation of Particulate Trace Metals. Analytical Chemistry, 51, 844-851. https://doi.org/10.1021/ac50043a017

[16] Rauret, G., López-Sánchez, J.F., Sahuquillo, A., Rubio, R., Davidson, C., Ure, A. and Quevauviller, P. (1999) Improvement of the BCR Three Step Sequential Extraction Procedure Prior to the Certification of New Sediment and Soil Reference Materials. Journal of Environmental Monitoring, 1, 57-61. https://doi.org/10.1039/a807854h

[17] Cuong, D.T. and Obbard, J.P. (2006) Metal Speciation in Coastal Marine Sediments from Singapore Using a Modified BCR-Sequential Extraction Procedure. Applied Geochemistry, 21, 1335-1346. https://doi.org/10.1016/j.apgeochem.2006.05.001

[18] Jalali, M. and Dayani, N. (2012) Heavy Metals (Cd, Cu, Ni, Pb, and Zn) Fractionation in River Sediments, Hamedan, Western Iran. Soil and Sediment Contamination: An International Journal, 21, 756-767. https://doi.org/10.1080/15320383.2012.678952

[19] Rath, P., Panda, U.C., Bhatta, D. and Sahu, K.C. (2009) Use of Sequential Leaching, Mineralogy, Morphology and Multivariate Statistical Technique for Quantifying Metal Pollution in Highly Polluted Aquatic Sediments-A Case Study: Brahmani and Nandira Rivers, India. Journal of Hazardous Materials, 163, 632-644. https://doi.org/10.1016/j.jhazmat.2008.07.048

[20] Loska, K., Wiechula, D., Barska, B., Cebula, E. and Chojnecka, A. (2003) Assessment of Arsenic Enrichment of Cultivated Soils in Southern Poland. Polish Journal of Environmental Studies, 12, 187-192.

[21] Acevedo-Figueroa, D., Jiménez, B.D. and Rodriguez-Sierra, C.J. (2006) Trace Metals in Sediments of Two Estuarine Lagoons from Puerto Rico. Environmental Pollution, 141, 336-342. https://doi.org/10.1016/j.envpol.2005.08.037

[22] Hakanson, L. (1980) An Ecological Risk Index for Aquatic Pollution Control.a Sedimentological Approach. Water Research, 14, 975-1001. https://doi.org/10.1016/0043-1354(80)90143-8

[23] Dang, Z., Liu, C. and Haigh, M.J. (2002) Mobility of Heavy Metals Associated with the Natural Weathering of Coal Mine Spoils. Environmental Pollution, 118, 419-426. https://doi.org/10.1016/S0269-7491(01)00285-8 
[24] Pagnanelli, F., Moscardini, E., Giuliano, V. and Toro, L. (2004) Sequential Extraction of Heavy Metals in River Sediments of an Abandoned Pyrite Mining Area: Pollution Detection and Affinity Series. Environmental Pollution, 132, 189-201. https://doi.org/10.1016/j.envpol.2004.05.002

[25] Gómez-Álvarez, A., Valenzuela-García, J.L., Aguayo-Salinas, S., Meza-Figueroa, D., Ramírez-Hernándezc, J. and Ochoa-Ortega, G. (2007) Chemical Partitioning of Sediment Contamination by Heavy Metals in the San Pedro River, Sonora, Mexico. Chemical Speciation \& Bioavailability, 19, 25-35.

https://doi.org/10.3184/095422907X198013

[26] Tessier, A. and Campbell, P.G.C. (1987) Partitioning of Trace Metals in Sediments: Relationships with Bioavailability. In: Thomas, R.L., Evans, R., Hamilton, A.L., Munawar, M., Reynoldson, T.B. and Sadar M.H., Eds., Ecological Effects of in Situ Sediment Contaminants, Springer, Netherlands, 43-52.

https://doi.org/10.1007/978-94-009-4053-6_5

[27] Islam, M.S., Ahmed, M.K., Raknuzzaman, M., Habibullah-Al-Mamun, M. and Islam, M.K. (2015) Heavy Metal Pollution in Surface Water and Sediment: A Preliminary Assessment of an Urban River in a Developing Country. Ecological Indicators, 48, 282-291. https://doi.org/10.1016/j.ecolind.2014.08.016

[28] Hseu, Z.Y. (2006) Extractability and Bioavailability of Zinc over Time in Three Tropical Soils Incubated with Biosolids. Chemosphere, 63, 762-771.

https://doi.org/10.1016/j.chemosphere.2005.08.014

[29] Dundar, M.S., Altundag, H., Eyupoglu, V., Keskin, S.C. and Tutunoglu, C. (2012) Determination of Heavy Metals in Lower Sakarya River Sediments Using a BCR-Sequential Extraction Procedure. Environmental Monitoring and Assessment, 184, 33-41. https://doi.org/10.1007/s10661-011-1944-7

[30] Sakan, S.M., Đorđević, D.S., Manojlović, D.D. and Predrag, P.S. (2009) Assessment of Heavy Metal Pollutants Accumulation in the Tisza River Sediments. Journal of Environmental Management, 90, 3382-3390.

https://doi.org/10.1016/j.jenvman.2009.05.013 